\title{
Making Shelter Work: Placing Conditions on an Employable Person's Right to Shelter
}

\author{
Dennis D. Hirsch
}

Homelessness in America is a problem of significant dimensions. Current estimates of the number of homeless ${ }^{1}$ vary from $250,000^{2}$ to $3,000,000,{ }^{3}$ with a recent count giving a figure of 500,000-600,000. ${ }^{4}$ This national tragedy has sparked many efforts to help. One of the major responses by members of the legal community has been to argue for a right to shelter that would obligate the government (generally state or local) to provide housing to all homeless persons who request it. ${ }^{5}$ Legal scholars have attempted to define the grounds for such a right, ${ }^{6}$ and litigators have brought lawsuits seeking to establish it. ${ }^{7}$

Generally, these advocates have argued for an unqualified guarantee of shelter to any person without a home. ${ }^{8}$ For example, in an early article Frank Michelman described the right to shelter as

an ironclad assurance that no one, no matter his profligacy or obstinacy, shall ever be deprived of decent shelter. Reference to a right to be

1. The homeless are generally defined as those lacking a permanent residence or living in public shelters, though a broader definition includes those living in unsafe or unsanitary housing. See, e.g., Chackes, Sheltering the Homeless: Judicial Enforcement of Governmental Duties to the Poor, 31 J. URB. \& CONTEMP. LAW 155, 155 (1987). Because this Note concerns the homeless who are living in the shelter system, it adopts the former definition.

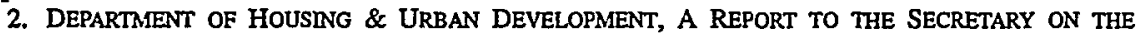
HOMELESS AND EMERGENCY SHELTERS (1984).

3. M. HOMBS \& M. SNYDER, HOMELESSNESS IN AMERICA: A FORCED MARCH TO NOWHERE Xvi (1983).

4. M. BURT \& B. COHEN, AMERICA'S HOMELESS: NUMBERS, CHARACTERISTICS, AND PROGRAMS THAT SerVe TheM 32 (Urban Institute Report 89-3, 1989).

5. See, e.g., Werner, Homelessness: A Litigation Roundup, 18 CLEARINGHOUSE REV. 1255 (1985).

6. See, e.g., Langdon \& Kass, Homelessness in America: Looking for the Right to Shelter, 19 COLUM. J.L. \& SOC. PROBS. 305 (1985); Seibert, Homeless People: Establishing Rights to Shelter, 4 LAW \& INEQUALITY 393 (1986); Note, A Right to Shelter for the Homeless in New York State, 61 N.Y.U. L. REV. 272 (1986).

7. See Callahan v. Carey, No. $42582 / 79$ (N.Y. Sup. Ct. Aug. 26, 1981) (final judgment by consent); McCain v. Koch, 502 N.Y.S.2d 720 (N.Y. App. Div. 1986); Eldredge v. Koch, 118 Misc. 2d 163, 459 N.Y.S.2d 960 (N.Y. Sup. Ct. 1983); Lubetkin v. City Manager of Hartford (Conn. Super. Ct. filed Feb. 4, 1983); Graham v. Schoemehl, No. 854-00035 (Mo. Cir. Ct. Nov. 15, 1985); Maticka v. Atlantic City, No. L-8306-84E (N.J. Super. Ct. Jan. 29, 1985); Hodge v. Ginsberg, 303 S.E.2d 245 (W. Va. 1983). See also Stille, Seeking Shelter in the Law, Nat'l L.J. Feb. 10, 1986; Werner, supra note 5.

8. An unqualified right to shelter for the homeless is defined as an obligation on the part of the state or local government to provide shelter to all homeless persons who request it, excepting only those whose behavior, such as setting fire to the shelter or assaulting other residents, impinges too strongly on another's enjoyment of his or her right to shelter. 
housed suggests ... an assurance that acceptable housing will be available irrespective of the market returns commanded by one's endowments of talent, influence, or capital; and irrespective, even, of voluntary choices in one's remote past which result in present inability to pay the true costs of acceptable housing. ${ }^{9}$

Recently, however, judges and legal commentators have begun to question the unqualified nature of the right to shelter and to argue that, where the right is established, it be more narrowly defined. For example, Judge Neely of the Supreme Court of West Virginia, dissenting in a case that established a right to shelter in that state, took issue with the majority opinion because

[it does] not establish with any particularity the class of people for whom the Commissioner is required to provide housing. Does it include people in certain income brackets only? Does it include those with sufficient income to pay rent who prefer to spend their income on alcohol? Does it include those who simply don't like the shelters currently run by charitable organizations? ... [T] he new program ... appears to contemplate permanent housing for anyone unwilling or unable to pay rent[.] Can anyone be turned down? ${ }^{10}$

A recent commentator offered a similar critique of right-to-shelter cases, stating that "[c]ourts that have recognized a legal right to shelter . . . have had difficulty defining the nature and the scope of the right.... [T] definition of a right to shelter is a major defect in decisions granting the right."11

Though voices such as these have begun to call for limits on the right to shelter, none as yet have suggested parameters for the right. This Note recommends a way for courts to proceed. While recognizing that the establishment of an unqualified right to shelter is, for some sectors of the shelter population, a positive development, it argues that, for the employable homeless, it is not. The Note will show that an unqualified right to shelter prevents the implementation of potentially useful policies targeted at this group. It will then argue that courts or settling parties establishing a right to shelter should define it more narrowly: the right should not extend to an employable homeless person who refuses, without good cause, to participate in an employment-related activity of which he or she is capable. Shelter administrators should be able to condition an employable person's right to shelter on such participation.

The Note will support this argument by examining New York City's experience with the right to shelter. In the 1979 case of Callahan v. Carey,

9. Michelman, The Advent of a Right to Housing: A Current Appraisal, 5 HARV. C.R.-C.L. L. REV. 207, 207 (1970).

10. Hodge v. Ginsberg, 303 S.E.2d 245, 252 (W. Va. 1983) (Neely, J., dissenting).

11. Comment, The Judiciary and the Ad Hoc Development of a Legal Right to Shelter, 12 HARV. J.L. \& PUB. POL'Y 193, 215-16 (1989) (footnote omitted). 
advocates for the homeless brought suit against the City and State of New York claiming that state constitutional and statutory law guaranteed a right to shelter for all homeless men in New York City. ${ }^{12}$ The litigation resulted in a consent decree effectively establishing an unqualified right to shelter.

This Note will show that in the years since the consent decree, increasing numbers of employable ${ }^{13}$ single adults have moved into the New York City shelters. ${ }^{14}$ By drawing on interviews with shelter administrators, and on current trends in social welfare policy, the Note will argue that the most effective way to help such people achieve self-sufficiency may well be to require them to participate in employment-related programs.

Under the current regime of an unqualified right to shelter, however, shelter administrators in New York City cannot implement such requirements because they cannot deny housing even to an employable person who refuses to participate in an employment-related program. Thus, an unqualified right to shelter constrains shelter administrators from testing new approaches that may be more effective in assisting shelter residents.

This Note suggests, therefore, that the parties to the Callahan litigation revise the consent decree so that it can permit administrators to implement employment-related requirements for employable shelter residents. Such a qualified right to shelter, the Note will show, is more consistent with the laws of New York State than is a broader right which would preclude requirements. The Note will also examine the constitutions of other states where lawsuits have established a right to shelter or where the basis for such a right might exist. This review will demonstrate that, as in New York, state law is consistent with placing employment-related conditions on the right to shelter of employable homeless persons. Courts finding a right to shelter should therefore define a narrower right which allows for such conditions.

12. Callahan v. Carey, No. $42582 / 79$ (N.Y. Sup. Ct. Aug. 26, 1981) (final judgment by consent).

13. An employable person is defined as one who is not unable to participate in employment- or trainingrelated activities due to significant incapacitation, either mental or physical. See, e.g., N.Y. SOC. SERV. LAW $\S 131(5)$ (Consol. Supp. 1989).

14. See infra notes 23-30 and accompanying text for a discussion of this change. While there have been other significant changes, such as the increasing numbers of homeless families utilizing New York City's shelters, these present quite different issues (e.g., the question of whether women with small children can or should be required to take on employment) which are beyond the scope of this Note. This Note will concern itself only with homeless single aduits, not with homeless families. 


\section{CALlahaN V. CAREY: THE CASE OF NEW YORK CitY}

The disadvantages of an unqualified right to shelter become evident when one examines how such a right operates in practice. This Note begins with a look at New York City's experience with a broad-reaching right to shelter.

\section{A. The Right-to-Shelter Litigation}

In Callahan v. Carey, ${ }^{15}$ a class of homeless men in New York City, represented by the Coalition for the Homeless (CFTH), sued the City and State of New York claiming that state constitutional and statutory law obligated defendants to provide them with food and shelter. The court granted plaintiffs' motion for a preliminary injunction requiring defendants to provide meals and lodging to those homeless men requesting it. ${ }^{16}$ In issuing the preliminary injunction, the court cited the legal sources on which plaintiffs had grounded their arguments, ${ }^{17}$ an indication that it was prepared to find a right to shelter based on New York State statutory and constitutional law. ${ }^{18}$ Possibly because they anticipated this, defendants agreed to a liberally worded consent decree settling the litigation. ${ }^{19}$ While the decree expressly left all issues of fact and law unresolved, ${ }^{20}$ it established, de facto, an unqualified right to shelter. ${ }^{21}$

15. Callahan v. Carey, No. $42582 / 79$ (N.Y. Sup. Ct. Aug. 26, 1981) (final judgment by consent).

16. Callahan v. Carey, N.Y.L.J., Dec. 11, 1979, at 10, col. 5 (N.Y. Sup. Ct. Dec. 10, 1979) (order granting preliminary injunction).

17. Id.

18. McKittrick, The Homeless: Judicial Intervention on Behalf of a Politically Powerless Group, 16 FORDHAM URB. L.J. 389, 406 n.111 (1988).

19. Id.

20. Callahan v. Carey, No. $42582 / 79$, at 2 (N.Y. Sup. Ct. Aug. 26, 1981) (final judgment by consent).

21. The decree obligates New York City to provide shelter and board to a class of homeless men defined as: "each homeless man who applies for it provided that (a) the man meets the need standard to qualify for the home relief program established in New York State; or (b) the man by reason of physical, mental or social dysfunction is in need of temporary shelter." Callahan v. Carey, No. $42582 / 79$, at 2-3 (N.Y. Sup. Ct. Aug. 26, 1981) (final judgment by consent). At first glance this provision may seem to establish a qualified right to shelter (i.e., conditioned on meeting eligibility requirements (a) or (b)), but in practice these "conditions" have proven impossible to implement, and New York's current policy is to provide a bed to any person who requests one. Interview with Karen Davis, Director of Operations for the New York City Adult Shelters, New York City Human Resources Administration in New Haven, Connecticut (Apr. 18, 1989). In large part, this situation stems from the phrase "social dysfunction," a term so broad that it has created a de facto entitlement for virtually everyone who applies. As one attorney for the New York City Human Resources Administration stated: "What is a 'social dysfunction'? How could we ask someone admitting applicants to assess whether an applicant suffers from a 'social dysfunction'? The City has got to give the term a broad reading and admit all who apply. We've got to err on that side of the issue, or risk a lawsuit." Interview with Dennis Young, Associate Attorney for the City of New York Human Resources Administration, in New York City (Apr. 25, 1989).

Later litigation extended the right to shelter established by the Callahan consent decree to homeless women, Eldredge v. Koch, 118 Misc. 2d 163, 459 N.Y.S.2d 960 (N.Y. Sup. Ct. 1983) (applying consent decree to women under equal protection analysis), and to homeless families, McCain v. Koch 117 A.D.2d 198, 212-14, 502 N.Y.S.2d 720, 729-30 (1986) (applying consent decree to homeless families under equal protection analysis). 


\section{B. Changes in the Shelter Population Lead to Changing Concerns}

To understand the policy implications of this unqualified right to shelter it is important, first, to become familiar with the make-up of the shelter population. In 1979, when the Callahan litigation began, the homeless plaintiffs were a relatively small group of highly incapacitated men, many of whom suffered from alcoholism, drug abuse, or mental illness. ${ }^{22}$ People in this condition are generally not able to participate in employment and training programs, which may explain why the parties to the initial litigation do not appear to have raised the issue of employment-related requirements.

In the years since the decree, however, the shelter population has changed in two ways that make employment-related activities much more relevant. First, the number of people using the shelters has increased dramatically. Fewer than 2,000 single adults utilized the shelter system each night in $1978 .{ }^{23}$ By the first half of fiscal year 1989, that number had expanded to $12,500 .{ }^{24}$ Cost has grown commensurate with size. Operating costs for New York City's homeless programs for adults have grown from $\$ 6.8$ million in 1978, to projected budgets (as of January 1988) of $\$ 156$ million in fiscal year 1988 and $\$ 285$ million in 1992. ${ }^{25}$ This growth in size and expense makes it important to focus not just on providing beds for the homeless, but also on how to help them become selfsufficient.

The second change which increases the importance of this issue is that in the years following the decree the homeless population has come to include an increasing number of employable persons who are able to participate in employment-related programs. One of the first studies to point to this population shift was a 1982 City of New York Human Resources Administration (HRA) report. ${ }^{26} \mathrm{HRA}$ researchers interviewing homeless men who had lived in the shelters for two months or more found that nineteen percent of those interviewed "had in the past been able to function at quite high levels, both occupationally and socially," and many did not suffer from any evident disabilities. ${ }^{27}$ As such, this group did not fit the 1979 mold of dysfunctional homeless.

Later studies have confirmed the finding that people with significant work histories and levels of functioning now make up a sizeable proportion of the shelter population. One study by the New York State Psychiatric Institute found that a considerable proportion of the shelter residents had recent work experi-

22. See infra notes 67-69 and accompanying text.

23. CitY OF NEW YORK HuMAN RESOURCES ADMINISTRation, REvision of the FIVE-YEAR PLAN FOR HOUSING AND ASSISTING HOMELESS SINGLE ADULTS 3 (1989).

24. Id.

25. CITY OF NEW YORK HUMAN RESOURCES ADMINISTRATION, FIVE-YEAR PLAN FOR HOUSING AND ASSISTING HOMELESS SINGLE ADULTS 49 (1988) [hereinafter FIVE-YEAR PLAN].

26. Main, The Homeless of New York, 72 PUB. INTEREST 3 (1983), reprinted in HousING THE HOMELESS 82 (J. Erickson \& C. Wilhelm eds. 1986) (discussing and describing at length 1982 HRA report entitled "Chronic and Situational Dependency: Long-term Residents in a Shelter for Men").

27. Id. at $92-93$. 
ence. ${ }^{23}$ In addition, the report found that twenty-one percent of the shelter residents were capable of independent living, and an additional forty-six percent could handle living in their own apartment with "modest" supportive services. ${ }^{29}$

A 1988 City of New York Human Resources Administration report also confirms this trend. According to this report, fully thirty-three percent of those utilizing the shelters in 1988 were "employable," meaning that they suffered from no "major barriers to employment, such as psychiatric, serious medical, or substance abuse problems, criminal histories, limited education, or lack of work experience." 30 These figures contradict the general perception of the homeless as an incapacitated group. They demonstrate that a sizeable percentage of the current homeless population could participate in, and potentially benefit from, employment-related programs.

\section{Extended Stays and Shelterization}

Studies which examine the course of an employable person's stay in the shelter system give added weight to the importance of helping these residents to find jobs and become independent. These studies show that many do not use the shelters simply as temporary stopping places but move in on a long-term basis. According to a recent Human Resources Administration report, fifty-four percent of the employable single adults who entered the shelters stayed for at least four months, and thirty-one percent remained for more than seven months. ${ }^{31}$

Moreover, recent evidence suggests that extended stays in the shelter system have just the type of deleterious effects on persons staying there that one would least like to see with regard to the employable homeless. An in-depth study of shelter residents carried out by the New York State Psychiatric Institute in 1988 documents that many of those who remain in the shelters for significant periods adapt to their surroundings, give up on getting back out on their own, and begin to see the shelters as their permanent home..$^{32}$ Many "eventually gave up the battle and adjusted to permanent living in the shelter system." ${ }^{13}$ This phenomenon appears to affect all residents, including those without mental or physical

28. N.Y. STATE PSYCHIATRIC INSTITUTE, A STUDY OF RESIDENTS OF THE NEW YORK CITY SHELTER SYSTEM 14-16 (1986) [hereinafter A STUDY OF RESIDENTS]. The researchers based their information on interviews with a representative sample of 832 male and female shelter residents. Twenty-nine percent of these, the report found, had worked for pay at least 20 hours per week for a month or more during the past five months. During the prior three years, $42 \%$ had worked at a paying job at least 20 hours per week for 13 months or more, and $19 \%$ had worked at such a job for 25 to 36 months during this period.

29. Id. at 75-76.

30. FIVE-YEAR PLAN, supra note 25 , at 10.

31. Id. at 57.

32. A STUDY OF RESIDENTS, supra note 28 , at $88-89$.

33. Id. at 87 . 
disabilities. ${ }^{34}$ As the report concluded, "[a]pparently when choices were limited, perceptions were altered and adaptation took place." ${ }^{35}$

A pair of researchers, including a psychiatrist from Columbia University, reached remarkably similar conclusions in a 1990 study of New York City shelter residents. The report identifies a process known as "shelterization" whereby residents adapt to the shelter as a permanent home and lose their drive to return to life on the outside. ${ }^{36}$ As one of the authors of the report stated, "[i]n short, people give in. They lose will and hope and all interest in improving themselves." ${ }^{37}$

These research findings indicate the development of a disturbing problem. Not only are substantial numbers of able-bodied people moving into the New York City shelter system, but many are staying for long periods and may be remaining on a permanent basis. To alleviate this problem it is important that shelter administrators develop effective means of aiding such people to achieve self-sufficiency.

D. How Most Effectively to Serve Employable Shelter Residents.

\section{Controversy in New York}

Those directly involved in working with employable homeless single adults express differing opinions about how best to help this group towards selfsupport and independent living. On the one hand, shelter administrators in New York stress the importance of requiring participation in some form of structured program-job placement, education or job training - as a way of combatting the apathy engendered by shelter life. For example, one New York City report cited the "need to develop employment referrals, supported work, and other means of fostering economic self-sufficiency"38 and stressed that "[i]t will be important to carefully assess client needs and resources, to impose appropriate structure and make appropriate demands on clients' own efforts. ${ }^{339}$

Karen Davis, former Director of Operations for the New York City Adult Shelters, supports this view, stating in an interview that "[a]ny way of introducing more structure would be helpful. We need to start creating some requirements since right now we ask nothing of our clients." ${ }^{20}$ Davis believes that it would make sense to condition employable shelter residents' right to shelter

34. Id. at 86-87.

35. Id. at 89.

36. N.Y. Times, May 24, 1990, at B14, col. 4.

37. Id.

38. CITY OF NEW YORK HUMAN RESOURCES ADMINISTRATION, NEW ARRIVALS: FIRST TMME SHELTER CLIENTS 2 (1982).

39. Id. (emphasis added).

40. Interview with Karen Davis, supra note 21. 
on participation in work experience programs coupled with job placement or skills training activities. ${ }^{41}$

Leading advocates for the homeless in New York, however, disagree with the notion of imposing requirements on shelter residents. Keith Summa of CFTH, for example, believes the homeless are strongly motivated to leave the shelters and will voluntarily take advantage of employment activities that increase their opportunity to become self-sufficient. ${ }^{42}$ Requiring participation, Summa contends, sets the wrong tone for the relationship between shelter provider and recipient and as a consequence is more destructive than helpful. ${ }^{43}$

\section{The Philadelphia Approach}

In New York, advocates and shelter administrators differ on the issue of employment-related requirements. This is, perhaps, predictable given the logic of their roles. If one were to find a case where advocates and administrators concurred, however, their shared opinion would be entitled to additional weight since agreement would indicate that their respective roles had not unduly shaped their viewpoints. Philadelphia provides such an example.

Philadelphia faced a homelessness situation in many respects similar to New York's: litigation established a broad, unqualified right to shelter, ${ }^{44}$ and this was followed by rapid increases in the size of the shelter population and in the cost of housing them. ${ }^{45}$ In Philadelphia, however, after three years experience with an unqualified right to shelter, the advocates who had brought the litigation and the shelter administrators whom they had sued, jointly agreed on employment-related requirements. ${ }^{46}$ They negotiated a new settlement which authorized the implementation of a client "protocol" whereby shelter applicants deemed employable were required to sign up for job-readiness, job-referral, and work-experience programs. The protocol gave shelter administrators the right to deny housing to employable shelter residents who refuse to comply with the conditions. ${ }^{47}$

41. Id.

42. Telephone interview with Keith Summa, CFTH (Nov. 14, 1989).

43. Id.

44. Philadelphia's right to shelter was initially put into place by a 1982 city ordinance passed by referendum. N.Y. Times, May 5, 1985, at 60, col. 3. In 1984, the Committee for Dignity and Fairness brought suit alleging inadequate provision of shelter and requesting an injunction to enforce the ordinance. Id. The parties settled by consent decree. See McKittrick, supra note 18, at 407 n.111.

45. In the three years following the consent decree the number of homeless using the Philadelphia shelters grew by $245 \%$. Whitman, Who's Who Among the Homeless: A Guide to Life on the Sireets, THE NEW REPUBLIC, June 6,1988 , at 18,20 . Expenditures on shelter rose from approximately $\$ 4$ million dollars in 1982 to over $\$ 23$ million in 1989 . Telephone interview with Steven Gold, General Counsel for the Committee for Dignity and Fairness (Nov. 20, 1989).

46. Telephone interview with Donald Felder, Outreach Administrator for the Philadelphia Office of Services to the Homeless and Adults (Nov. 7, 1989).

47. Id. The client protocol also requires substance abusers to sign up for treatment programs and requires those with an income from earnings or benefits to save a portion of it in anticipation of paying rent for an apartment. 
It is especially interesting to examine the Philadelphia advocates views on the need for employment-related requirements, since their perspective differs so sharply from that of their New York counterparts. Steven Gold, General Counsel for the Committee on Dignity and Fairness, the group which brought the original right-to-shelter litigation in Philadelphia, and Phyllis Ryan, Executive Director of the Philadelphia Committee on the Homeless, both initially resisted the idea of requirements but eventually concluded that they were necessary and desirable..$^{48}$ According to Gold, a guaranteed right to shelter creates passivity both in the political sphere, where the homeless will be less likely to lobby for the building of more low-income housing, and in the personal sphere, where people become more dependent. ${ }^{49}$ Employment-related requirements are one way to combat the debilitating effects of shelter life. In Gold's words, it is "absolutely critical to implement requirements, for people who are feeling psychologically down and disconnected may not take these steps voluntarily." ${ }^{\prime 50} \mathrm{He}$ recommends a model that his organization has implemented, run by the homeless themselves and mandating participation in employment, education, and community activities. Similarly, Ryan states that "we realized that in order to be most helpful we had to encourage the clients to take responsibility. They suffer from a great lack of self-esteem, and to get it back we need to encourage them to take on the task of shaping their own lives." These are not words one would expect to hear from advocates for the homeless. Their source, and the experience on which they are based, make them especially worthy of consideration.

\section{Insights From the AFDC Program}

Lessons from the Aid to Families with Dependent Children (AFDC) program provide additional support for employment-related requirements. Research has shown that mandatory employment and training programs for welfare recipients can help raise the employment and earnings levels of participants and can be cost-effective. ${ }^{52}$ This research provided support for the Family Support Act of 1988, which refocused the AFDC system to emphasize mandatory education, job search, and skills training programs. ${ }^{53}$ The Act differs from

To date, no one has challenged the Philadelphia consent decree or the client protocols promulgated under it. This may be because the conditions agreed upon by the parties are consistent with the state laws. Alternatively, it may reflect the fact that advocacy groups, who helped develop the decree and protocols, do not wish to challenge them.

48. Telephone interview with Steven Gold, supra note 45. Telephone interview with Phyllis Ryan, Executive Director of the Philadelphia Committee for the Homeless (Nov. 7, 1989).

49. Telephone interview with Steven Gold, supra note 45.

50. Id.

51. Telephone interview with Phyllis Ryan, supra note 48.

52. S. REP. NO. 377, 100th Cong., 2nd Sess. 9, reprinted in 1988 U.S. CODE CONG. \& ADMIN NEWS 2776, 2786.

53. Id. at 3-4, reprinted in 1988 U.S. CODE CONG. \& ADMIN. NEWS, at 2780. 
prior approaches in that it seeks to increase the level of responsibility expected of clients at the same time as it augments the amount of services provided to them. Since both the AFDC program and the shelters serve highly dependent populations, the strong evidence and conclusions informing the Family Support Act provide support, by analogy, for those who advocate employment-related requirements for the employable homeless.

The AFDC experience also suggests an answer to the question of how to generate funding to pay for employment-related programs for the homeless. Because the Family Support Act combined increased client obligation with increased services, it broke new ground by receiving support both from conservatives, who agreed with the emphasis on client responsibility, and liberals, who liked the increase in supportive programs. ${ }^{54}$ If employment-related requirements created a similar consensus with regard to programs for the homeless, they might increase the probability that proposals to fund increased services would be approved.

\section{E. The Disadvantages of an Unqualified Right to Shelter}

Social scientists have not yet directly proven the viability of mandatory employment-related programs for the homeless. The prior section has tried to show, however, that the issue is, at the very least, an open one. The interviews discussed above, and the evidence from the AFDC area, suggest that required skills training, job search, job placement, work experience, or education programs may well be the most effective way of aiding the employable homeless. ${ }^{55}$ Shelter administrators should, therefore, have the opportunity to try out

54. "[The bill] builds on a strong consensus, joined by liberals and conservatives alike, that the Nation's welfare system must stress family responsibility and community obligation...." Id. at 8, reprinted in 1988 U.S. CODE CONG. \& ADMIN. NEWS, at 2785. See also Gueron, Work and Welfare: Lessons on Employment Programs, 4 J. ECON. PERSP. 79, 84 (forthcoming article) (Family Support Act represents compromise between liberal and conservative views of welfare reform).

55. Other commentators have suggested that requirements would be a useful means of getting the employable homeless to move towards employment and self-sufficiency. Thomas Main has proposed a work requirement for employable shelter residents which would deter them from using the shelter system and would send the message that society expects them to become self-supporting. Main, supra note 26, at 10304. Robert Ellickson has also stated that employable shelter residents "must be encouraged to enter the job market," though he does not go so far as to suggest employment and training programs. Ellickson, The Homelessness Muddle, 99 PUB. INTEREsT 45, 59 (1990). These proposals, however, do not include enough in the way of services. The mandatory employment and training programs envisioned by this Note would include such components as skills training, job placement, job search, work experience, or education programs.

Such employment-related activities might be questioned on the grounds that high levels of unemployment, commonly assumed to be one of the causes of homelessness, make employment and training programs unlikely to succeed. Where there are few jobs to be found, some might argue, it makes less sense to require shelter residents to prepare for and seek work.

It is true that employment and training programs will be less effective in economically depressed areas of the country, and more likely to show positive results in those regions where there are jobs. However, programs which train shelter residents in new work-related skills, or even in job search techniques with which they were not previously familiar, will better equip them to find work even in regions of significant unemployment. In addition, required program participation will keep shelter residents involved in work- 
mandatory programs.

The unqualified right to shelter is problematic because it prevents such testing. By not allowing administrators to withhold shelter except in the most severe circumstances (e.g. violent behavior), it denies them the only effective means of sanctioning those who refuse to participate in mandated employment and training activities. Administrators cannot, therefore, set up meaningful requirements.

Shelter administrators in New York have run up against this problem. Attorneys for the Human Resources Administration state that while the Department has considered requirements of various types, it has not implemented them for fear of violating the guarantees of the consent decree and provoking further litigation. ${ }^{56}$ Advocates for the homeless affirm that if employment-related requirements were adopted they would sue New York City to prevent their implementation. ${ }^{57}$ Perhaps for this reason, New York City has put into place only voluntary employment-related activities. ${ }^{58}$

For New York City policymakers contending with the size and long-term dependency of the shelter population, this is not a satisfactory solution. They would prefer to have the option of implementing requirements. ${ }^{59}$ Thus while a broad right to shelter may have been appropriate for the relatively small, incapacitated homeless population on whose behalf CFTH brought the initial Callahan litigation in 1979, it is not the correct solution for a population that includes significant numbers of employable homeless persons. ${ }^{60}$

\section{F. A More Narrowly Defined Right to Shelter}

This Note suggests that the parties to the Callahan litigation revise their consent decree to allow for employment-related conditions on the right to shelter. ${ }^{61}$ For example, the eligibility section of the Callahan consent decree ${ }^{62}$ could be modified to read:

related activities, helping them to combat the apathy and discouragement associated with life in the shelters and with unemployment. When the economy improves, they will then be better able to reenter the workforce.

56. Interview with Dennis Young, supra note 21.

57. Telephone interview with Keith Summa, supra note 42.

58. FIVE-YEAR PLAN, supra note 25 , at 24.

59. See supra notes $38-41$ and accompanying text.

60. As one attorney for the HRA stated: "[The consent decree] prevents us from implementing the appropriate policies. For seventy percent of the shelter population, you can deal with them without violating the decree. For that other thirty percent [i.e., the functional and employable residents] though, the decree makes it extraordinarily difficult to deal with them." Interview with Dennis Young, supra note 21.

61. New York case law supports the idea that, in institutional reform litigation, consent decrees can be modified "with a free hand." New York State Ass'n for Retarded Children v. Carey, 706 F.2d 956, 970 (2d Cir. 1983) (modification of consent decree governing community for mentally retarded allowed so long as not in derogation of primary objective of decree). Moreover, in the Callahan $v$. Carey consent decree the court specifically retained jurisdiction to enable the parties to apply for any modifications which might be "necessary or appropriate." Callahan v. Carey, No. $42582 / 79$ at 15.

62. See supra note 21 . 
The City defendants shall provide shelter and board to each homeless person who applies for such, provided that (a) the person by reason of physical or mental dysfunction is in need of temporary shelter; or (b) the person meets the need standard to qualify for the Home Relief program established in New York State, except that the City defendants may, in their discretion, deny shelter to an employable homeless person who refuses, without good cause, to participate in employment- or training-related activities of which he or she is capable and which are intended to enable him or her to achieve self-support.

Language such as this would permit administrators to implement mandatory employment and training programs. As discussed above, no one has yet conclusively established that such programs will prove effective. Interviews with shelter administrators and advocates in Philadelphia, and the studies showing the positive effects of employment-related requirements in the welfare area, however, indicate that these programs may well have beneficial results. ${ }^{63}$ Redefining New York's right to shelter in the manner suggested by this Note will allow shelter administrators to test the effectiveness of these potentially useful programs.

\section{Conditions on an Employable Person's Right to Shelter ARe CONSISTENT WITH THE LAWS OF NEW YORK STATE}

The recommendat ${ }_{2}$ on just stated may be beside the point. New York City is, after all, subject to a right to shelter established though litigation. If New York statutory and constitutional law compel an unqualified right to shelter, then the Callahan parties are constrained by this (at least until the legislature amends a controlling statute). The Callahan court's acceptance of plaintiffs' legal arguments in issuing the preliminary injunction makes it appear that the parties are constrained in this manner. ${ }^{64}$ Importantly, however, the Callahan consent decree left all issues of law and fact unadjudicated ${ }^{65}$ No New York court opinion has settled this question on the merits.

This section will argue that shelter administrators would not offend New York law by placing employment-related conditions on the right to shelter of employable single adults. It will show that the plaintiffs' legal arguments in Callahan, and the court's opinion in issuing the preliminary injunction, depend on a perception of the homeless as a group of incapacitated persons. This concept of the homeless population is seriously out of date. Approximately onethird of those now living in New York's shelters are employable. ${ }^{66}$ This sec-

\footnotetext{
63. See supra notes 44-55 and accompanying text.

64. See supra notes 16-18 and accompanying text.

65. See supra note 20 and accompanying text.

66. See supra notes $26-30$ and accompanying text.
} 
tion will reexamine plaintiffs' legal arguments in light of this change. It will argue that, with regard to the employable homeless, New York law does not preclude placing employment-related conditions on the right to shelter.

\section{A. Premises of the Right-to-Shelter Litigation}

Both the parties and the court in Callahan clearly viewed the homeless as a group of incapacitated individuals. For example, the plaintiffs' memo in Callahan supporting their motion for a preliminary injunction described the homeless population as "homeless men living in New York City, the overwhelming majority of whom are incapacitated due to physical and mental disabilities, often exacerbated by alcohol and drug addictions." ${ }^{\text {"67 }}$ Similarly the court, in issuing its preliminary injunction, described the group as "destitute and homeless alcoholics, addicts, mentally impaired derelicts, flotsam and jetsam"68 and cited the Commissioner of the State Department of Social Service's description of the homeless as "'largely composed of individuals with histories of alcohol abuse, drug abuse, mental disorder or combination thereof. These conditions are chronic and seriously preclude or prevent independent functioning." "69 This perception of the homeless as people suffering from some form of disability served as a key premise of the Callahan plaintiffs' constitutional and statutory arguments.

\section{The State Constitution}

Plaintiffs relied on section 1 of Article XVII of the New York State Constitution, which reads: "The aid, care and support of the needy are public concerns and shall be provided by the state and by such of its subdivisions, and in such manner and by such means, as the legislature may from time to time determine." 70 To construe this as a basis for a right to shelter, CFTH relied on a New York Court of Appeals decision, Tucker v. Toia. ${ }^{71}$ The Tucker court interpreted the provision to mean that while the state retains "discretion in determining the means by which this objective is to be effectuated ... and in classifying recipients and defining the term 'needy,' [the state constitution] unequivocally prevents the Legislature from simply refusing to aid those whom it has classified as needy."72 The state, then, defines the term "needy," but

67. Memorandum of Plaintiffs in Support of Their Motion for a Preliminary Injunction at 2, Callahan v. Carey, N.Y.L.J., Dec. 11, 1979, at 10, col. 5 (N.Y. Sup. Ct. Dec. 10, 1979) (No. 42582/99) [hereinafter Plaintiffs' Memorandum].

68. Callahan v. Carey, N.Y.L.J., Dec. 11, 1979, at 10, col. 5 (N.Y. Sup. Ct. Dec. 10, 1979).

69. Id.

70. N.Y. CONST. art. XVI, $\S 1$.

71. Tucker v. Toia, 43 N.Y.2d 1, 371 N.E.2d 449, 400 N.Y.S.2d 728 (1977).

72. Id. at 8,371 N.E.2d at 452,400 N.Y.S.2d at 731 . 
once they have defined the term so that it covers a certain group they become obligated to provide aid to that group.

In Callahan, because the court and parties viewed the homeless as highly incapacitated, they accepted the "neediness" of this group without dispute. Plaintiffs, in their memo in support of the preliminary injunction, stated that "[o]bviously, indigent, homeless men seeking shelter are needy."73 Defendants did not challenge this, probably because it seemed "obvious" to them as well. ${ }^{74}$ The court, in granting the preliminary injunction, accepted that the homeless were "needy" and enforced the state obligation that follows from this. The perceived incapacitation of the homeless in 1979 was, therefore, an essential element of plaintiffs' state constitutional argument.

\section{State Statutory Law}

As a second argument, the Callahan plaintiffs claimed that sections 131 and 62 of the New York State Social Services Law supported a right to shelter. They premised this assertion, too, on the incapacities of the 1979 homeless. Section 131 makes it the duty of state officials to "provide adequately for those unable to maintain themselves ...."75 Section 62 makes this obligation binding on local service providers such as New York City. ${ }^{76}$ As with the term "needy" in Article XVII of the state constitution, the determination that a group is "unable to maintain themselves" affirmatively obligates the state to provide aid to them. ${ }^{77}$ The incapacities of the homeless population as it existed in 1979 allowed the plaintiffs in Callahan to define their class as "homeless men ...

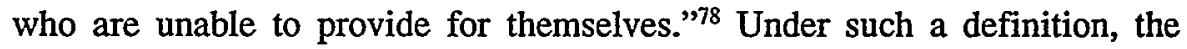
homeless easily fit within the standards of sections 131 and 62 . The defendants did not oppose this characterization in their memorandum. ${ }^{79}$ Thus the incapacities of the homeless were integral to the Callahan plaintiffs' statutory argument as well.

\section{B. The Arguments Reexamined}

The premises of plaintiffs' arguments no longer hold for a significant proportion of shelter residents. As demonstrated above, up to thirty-three percent of the homeless single adults inhabiting the New York City shelters are

73. Plaintiffs' Memorandum, supra note 67 , at 11.

74. See City Defendants' Memorandum of Law, Callahan v. Carey, N.Y.L.J., Dec. 11, 1979, at 10, col. 5 (N.Y. Sup. Ct. Dec. 10, 1979) (No. 42582/79) [hereinafter Defendants' Memorandum].

75. N.Y. SOC. SERV. LAW $\$ 131(1)$ (Consol. 1984).

76. N.Y. SOC. SERV. LAW \& 62 (Consol. 1984).

77. Barie v. Lavine, 40 N.Y.2d 565, 567-68, 357 N.E.2d 349, 350-51, 388 N.Y.S.2d 878, 879-80 (1976).

78. Plaintiffs' Memorandum, supra note 67 , at 2.

79. Defendants' Memorandum, supra note 74. 
functional and employable, not incapacitated ${ }^{80}$ Reexamined in this light, the state constitutional and statutory grounds advanced by the Callahan plaintiffs can be shown to be consistent with a right to shelter that permits requiring an employable person to participate in employment-related activities.

\section{Conditions are Consistent With the State Constitution}

As mentioned above, ${ }^{81}$ plaintiffs based their state constitutional argument on the assertion that the homeless were "needy." New York courts have interpreted the term "needy," however, to exclude those employable persons who refuse to participate in employment-related programs and so contribute to the creation of their own need.

In Barie v. Lavine, the New York State Court of Appeals considered a case in which the state had sanctioned the Home Relief benefits of a poor but employable woman who had failed, without good cause, to attend a mandatory job interview. ${ }^{82}$ The court held that the regulation under which the state sanctioned her grant did not violate the state's constitutional duty to aid the needy because

[s] ection 1 of article XVII of the New York State Constitution mandates only that the "needy" and those unable to care for themselves be afforded aid and support.... The Legislature may in its discretion deny aid to employable persons who may properly be deemed not to be needy when they have wrongfully refused an opportunity for employment. ${ }^{83}$

The Appellate Division in Barie offered the clearest rationale for this decision, stating that:

While the objective facts of hunger and a lack of sufficient assets to provide for one's own food, shelter and clothing establish prima facie a "needy" person, nevertheless, the word "needy" does not in its ordinary meaning encompass a person who is creating the need by consistently avoiding or refusing to provide for his needs. ${ }^{84}$

Under Barie, a person who is capable of participating in required employment-related activities but refuses, without good cause, to do so can be declared not "needy." The state, then, has no duty to provide aid to him or her. This holding has been reaffirmed consistently by New York courts. ${ }^{85}$

80. See supra notes $26-30$ and accompanying text.

81. See supra notes $70-74$ and accompanying text.

82. Barie v. Lavine, 40 N.Y.2d 565, 566, 357 N.E.2d 349, 350, 388 N.Y.S.2d 878, 879 (1976).

83. Id. at 570,357 N.E.2d at 352,388 N.Y.S.2d at 881 .

84. Barie v. Lavine, 48 A.D.2d 36, 38, 367 N.Y.S.2d 587, 590 (N.Y. App. Div. 1975).

85. See e.g. Kircher v. Perales, 112 A.D.2d 431, 433, 492 N.Y.S.2d 91, 94 (N.Y. App. Div. 1985) ("The Legislature has great discretion in setting criteria for defining the needy. ... Moreover, the Legislature is free to exclude those who have purposely created their own 'need' in order to qualify for assistance." 
While it might be argued that a shelter resident is distinguishable from a Home Relief recipient in that the very roof over his or her head is at stake, the Barie court's holding can be applied to the homeless. The Appellate Division in Barie explicitly recognized that Ms. Barie might be deprived of shelter as a result of the sanction, but upheld the regulation nonetheless. ${ }^{86}$ Thus a shelter administrator could condition an employable shelter resident's benefits on the fulfillment of certain employment-related requirements without running afoul of the state constitution.

\section{Conditions are Consistent with State Statutory Law}

Reexamining New York State statutory law in light of the changed nature of the homeless population shows that state statutes, like the state constitution, do not guarantee an unqualified right to shelter to the employable homeless. In 1979, the plaintiffs in Callahan could argue that the incapacitated homeless were $a$ priori "unable to provide for themselves" and so were covered by sections 131 and $62 .{ }^{87}$ An employable person who refuses to participate in employment-related activities, however, is able to take steps towards selfsupport. By definition, such a person is capable of participating in services which might allow him or her to become self-sufficient. The state, therefore, has no obligation to provide for such a person. In this respect, sections 131 and 62 are consistent with section 1, Article XVII of the state constitution.8

Moreover, section 131 explicitly provides that the state may condition an employable person's right to benefits on compliance with employment-related requirements. The statute states that "[n]o assistance or care shall be given to an employable person who has not registered with the nearest local employment agency ... or has refused to accept employment in which he is able to engage." $\$ 9$ The statute defines refusal to accept employment to include not only turning down a job, but also failing, without good cause, to report for a job interview, ${ }^{90}$ failing to attend scheduled counseling, training or other appropriate job services, ${ }^{91}$ or failing to participate in any other employment program deemed appropriate by local social service officials. ${ }^{92}$ Rather than foreclosing

(citations omitted)); Flynn v. Bates, 67 A.D.2d 975, 977, 413 N.Y.S.2d 446, 448 (N.Y. App. Div. 1979) (noting that the word "needy" does not encompass one who refuses to provide for his or her own needs); Harrington v. Blum, 117 Misc. 2d 623, 624 (N.Y. Sup. Ct. 1982) ("The word 'needy' does not encompass a person who may create that need by failing or refusing to provide for her own needs.").

86. Barie v. Lavine, 48 A.D.2d 36, 38, 367 N.Y.S.2d 587, 589-90 (N.Y. App. Div. 1975).

87. See supra notes 75-79 and accompanying text.

88. See Barie v. Lavine, 48 A.D.2d 36, 38-39, 367 N.Y.S.2d 587, 590 (N.Y. App. Div. 1975); Hudson v. Sipprell, 76 Misc. 2d 684, 687, 351 N.Y.S.2d 915, 920 (N.Y. Sup. Ct. 1974).

89. N.Y. SOC. SERY. LAW § 131(5) (Consol. Supp. 1989).

90. N.Y. SOC. SERV. LAW § 131(5)(c) (Consol. Supp. 1989).

91. N.Y. SOC. SERV. LAW § 131(5)(g) (Consol. Supp. 1989).

92. N.Y. SOC. SERV. LAW $\S 131(7-a)(a)(g)$ (Consol. Supp. 1989). 
employment-related conditions on the right to shelter, section 131 provides a basis on which to ground these conditions. ${ }^{93}$

In sum, neither the state constitution nor the statutory sources on which the litigants in Callahan based the right to shelter would preclude the parties from revising the consent decree to allow for employment-related conditions on an employable person's right to shelter.

\section{Conditions on an Employable Person's Right to Shelter are CONSISTENT WITH THE LAWS OF OTHER JURISDICTIONS}

Thus far, this Note has focused on New York State, arguing that the interested parties there can and should revise their consent decree to allow for employment-related conditions on the right to shelter of employable persons. New York, however, is not the only jurisdiction in which representatives of the homeless have brought right-to-shelter litigation. Such cases have also been brought in: Atlantic City, New Jersey; St. Louis, Missouri; Hartford, Connecticut; and the State of West Virginia. ${ }^{44}$ The amount of attention directed at the homelessness issue suggests that more cases are likely to follow. Moreover, studies have documented that, as in New York, the homeless population thoughout the country is comprised of a sizeable number of employable persons. ${ }^{95}$ Thus, the question of placing conditions on the right to shelter of employable homeless persons has national relevance.

This Note maintains that courts thoughout the country who find a right to shelter should narrowly construe that right so that it does not preclude employment-related requirements. This Section will demonstrate that, as in New York, the laws of other states are consistent with such a qualified right. ${ }^{96}$ This review focuses on state constitutional law because advocates for the homeless, responding to the lack of federal or common law grounds for a right to shelter, ${ }^{97}$ have based their arguments primarily on state law. ${ }^{98}$

93. See Barie v. Levine, 40 N.Y.2d 565, 567-68, 357 N.E. $2 d$ 349, 350-51, 388 N.Y.S.2d 878, $879-80$ (1976).

94. See supra note 7.

95. Hagen, The Heterogeneity of the Homeless, 66 SOC. CASEwORK 451, 456-57 (1987). The nature of homelessness, of course, varies in different parts of the country, and New York's homeless population is in some respects exceptional. See P. ROSsI, DOWN AND OUT IN AMERICA (1989) (surveying homelessness in various parts of the United States).

96. This section draws on a thorough and useful survey of state law provided by Langdon \& Kass, supra note 6 , at $324-34$.

97. The Supreme Court has indicated that the federal Constitution contains no right to shelter. See Lindsey v. Normet, 405 U.S. 56, 74 (1972). No federal statutory right currently exists, and there does not appear to be a common law duty to provide assistance to the poor. See, e.g., State v. City of Bristol, 139 Conn. 469, 95 A.2d 78 (1953); People ex rel. Heydenreich v. Lyons, 374 IIl. 557, 30 N.E.2d 46 (1940).

98. In addition to state constitutions, parties seeking a right to shelter might also rely on two other state law sources: general assistance statutes, see, e.g., Callahan v. Carey, N.Y.L.J., Dec. 11, 1979, at 10, col. 5 (N.Y. Sup. Ct. Dec. 10, 1979), and state adult protective statutes, see, e.g., Hodge v. Ginsberg, 303 S.E.2d 245,252 (W. Va. 1983). 
Many state constitutions do not offer direct support for a right to shelter. Even those that do, however, do not bar employment-related conditions on an employable person's right. To bar such conditions the state constitution would have to impose such a strong duty on the state that it would be unconstitutional to deny a bed even to a shelter resident who, although capable of participating in an employment program to which he or she was assigned, failed, without good cause, to do so. None would appear to create such an absolute duty.

The constitutions of thirty-three states do not contain any provisions dealing directly with aid to the poor. ${ }^{99}$ They do not, therefore, offer explicit support for any form of a right to shelter, let alone an unqualified right.

There are seventeen state constitutions that do contain provisions concerning aid to the poor. Yet these too are unlikely to provide for an unqualified right to shelter. Two employ language wholly unrelated to the right-to-shelter issue. ${ }^{100}$ Four empower the state or local governments to aid the poor but create no affirmative obligation to do $\mathrm{so}^{101}$ and would, therefore, be highly unlikely to create any duty to provide shelter to the homeless. ${ }^{102}$

Five of the seventeen state constitutions do require the state to provide for the poor but contain only broadly worded language requiring the government

\footnotetext{
General assistance statutes, such as section 131 relied upon in the Callahan litigation, establish programs that provide a minimal amount of aid to poor people not eligible for categorical federal programs. Even where these statutes could be construed to create a right to shelter, however, they would not create an unqualified right since most contain eligibility requirements that would permit placing employment-related conditions on an employable person's right. For example, the Virginia general assistance statute provides that "[n]o person shall be deemed to be in need of general relief, however, if he fails to accept available employment which is appropriate to his physical and mental abilities and training ...." VA. CODE ANN. $\S 63.1-106$ (1987).

Adult protective statutes require local or state officials to provide protective services to incapacitated adults who they determine to be abused, neglected, exploited or endangered. See, e.g., MICH. COMP. LAWs ANN. $\S \S 400.11-400.11$ (West 1988). In Hodge v. Ginsberg advocates for the homeless in West Virginia successfully grounded a right to shelter on such a statute by arguing that lack of shelter and food creates a risk of death or injury which "endangers" homeless adults. Hodge v. Ginsberg, 303 S.E.2d 245, 252 (W. Va. 1983). Like general assistance statutes, however, most adult protective statutes would not provide grounds for an unqualified right to shelter. Most cover only "incapacitated" adults, disabled by mental or physical dysfunction or by age. Michigan's adult protective statute is representative. The statute applies only to those who are "[v]ulnerable," defined as "a condition in which an adult is unable to protect himself or herself . . . because of a mental or physical impairment or because of the frailties or dependencies brought about by advanced age." MICH. COMP. LAWs ANN. \$ 400.11.(g). Employable shelter recipients would not, by definition, fit into such a category and so could not look to these statutes as grounds for an unconditional right to shelter.

99. See Langdon \& Kass, supra note 6, at 332-34. They include in this category: Alaska, Arizona, Arkansas, California, Connecticut, Delaware, Florida, Georgia, Illinois, Iowa, Kentucky, Louisiana, Maine, Maryland, Massachusetts, Michigan, Minnesota, Nebraska, New Hampshire, New Jersey, New Mexico, North Dakota, Ohio, Oregon, Pennsylvania, Rhode Island, South Dakota, Tennessee, Utah, Vermont, Virginia, Washington, and Wisconsin.

100. The Colorado Constitution provides only that those residents who have reached age 60 receive a pension, COLO. CONST. art. XXIV, $\S 3$, and the West Virginia Constitution states simply that the county courts should appoint "overseers of the poor," W. VA. CONST. art. IX, § 2.
}

101. See HAW. CONST. art. IX, § 3; IND. CONST. art. IX, § 3; Miss. ConST. art. IV, § 86; MONT. CONST. art. 12, § 3(3).

102. See Langdon \& Kass, supra note 6, at 333. 
to create public or charitable institutions. ${ }^{103}$ The Wyoming Constitution, for example, provides that "[s]uch charitable, reformatory and penal institutions as the claims of humanity and the public good may require, shall be established and supported by the state in such manner as the legislature may prescribe."104 These general words would not appear to create an affirmative obligation on the part of the state to house the homeless. ${ }^{105}$ Even if this language were read to mandate homeless shelters as institutions required by "claims of humanity," the provision only prescribes the creation of an institution. The nature of the institution, its eligibility requirements, and its procedures are explicitly delegated to "the legislature," which would be free to place conditions upon entry into the shelter system.

The six remaining state constitutions provide more specifically for aid to the poor and present the closest cases. This Note has already considered one of these, the New York Constitution. ${ }^{106}$ Two others, the North Carolina and Texas Constitutions, contain provisions which are of such narrow scope that they would not impede placing conditions on a right to shelter. ${ }^{107}$

The Oklahoma and Kansas Constitutions contain a broader duty to aid the poor, yet this obligation only reaches those who are needy due to "age, infirmity, or misfortune." 108 While this language may support a right to shelter, it does not preclude placing conditions on an employable person's right. Such a person is not, by definition, unable to function due to "age or infirmity." Nor does a person who has refused to participate in an employment-related activity need aid due to "misfortune" since this word implies "an instance of bad luck," 109 not the failure to do something one is capable of doing. ${ }^{110}$

Finally, the Alabama Constitution contains the broadest language concerning aid to the poor: "It shall be the duty of the legislature to require the several counties of this state to make adequate provision for the maintenance of the poor."111 If "maintenance" were held to include shelter, this provision might be construed to provide a right to shelter for all poor persons, employable or not, and so might preclude conditioning their right. On the other hand, it could

103. See IDAho ConsT. art. X, $\S 1$; MO. Const. art. IV, $\$ 37$; NEv. Const. art. XIII, § 1; S.C. Const. art. XII, § 1; WYO. CONST. art. 7, § 18 .

104. WYO. CONST. art. VII, $\$ 18$.

105. See Langdon \& Kass, supra note 6 , at 332.

106. See supra notes $81-86$ and accompanying text.

107. The North Carolina Constitution requires only that the legislature "provide for and define the duties of a board of welfare." N.C. CONST. art. XI, $\S 4$. The Texas Constitution mandates "the establishment of county poor houses and farms," but appears to leave to the legislature discretion to determine the practical details such as conditions for entry. TEX. CONST. art. XI, § 2 .

108. OKLA. CONST. art. XVII, $\S 3$. ("The several counties of the State shall provide, as may be prescribed by law, for those inhabitants who, by reason of age, infirmity, or misfortune, may have claims upon the sympathy and aid of the county.") See also KAN. CONST. art. VII, § 4.

109. WEBSTER's THIRD NEW INTERNATTONAL DICTIONARY 1443 (1986).

110. The Fifth Circuit construed "misfortune," as used in this context, to exclude the "[a]blebodied ... [who] are deemed indigent by choice and, as a matter of public policy, not entitled to maintenance." Brennan v. Harrison County, 505 F.2d 901, 903 (5th Cir. 1975).

111. ALA. CONST. art. IV, $\$ 88$. 
be argued that providing shelter for employable persons only on the condition that they participate in employment-related programs is "adequate provision," especially where such requirements are intended to prevent dependency and shelter-induced apathy.

In sum, a review of state constitutions illustrates that the great majority, if not all, would permit placing employment-related conditions on an employable person's right to shelter. For the reasons discussed above, ${ }^{112}$ courts finding a right to shelter should narrowly construe it to allow for such conditions.

\section{CONCLUSION}

Considerable numbers of employable persons currently live in our nation's shelters. What can the legal community do that will best help such people to achieve self-sufficiency? This Note has argued that an unqualified right to shelter is not the optimal approach. Such a right precludes employment-related requirements that may well be the most effective means of assisting the employable homeless to fight the debilitating effects of shelter life and to take steps towards independence. ${ }^{113}$ This Note recommends, therefore, that where courts or settling parties define a right to shelter they adopt a narrower formulation permitting employment-related conditions on an employable person's right.

112. See supra notes $\mathbf{3 8 - 5 5}$ and accompanying text.

113. See supra notes $38-55$ and accompanying text. 